\title{
Bioactive Antimicrobial Peptides as Therapeutics for Corneal Wounds and Infections
}

\author{
Gina L. Griffith, ${ }^{1}$ Anne Kasus-Jacobi, ${ }^{2,3}$ and H. Anne Pereira ${ }^{2-5, *}$ \\ ${ }^{1}$ Ocular Trauma and Vision Restoration, United States Army Institute of Surgical Research, Fort Sam Houston, Texas. \\ ${ }^{2}$ Department of Pharmaceutical Sciences, University of Oklahoma Health Sciences Center, Oklahoma City, Oklahoma. \\ ${ }^{3}$ Oklahoma Center for Neuroscience, University of Oklahoma Health Sciences Center Oklahoma City, Oklahoma. \\ Departments of ${ }^{4}$ Pathology and ${ }^{5}$ Cell Biology, University of Oklahoma Health Science Center, \\ Oklahoma City, Oklahoma.
}

Significance: More than 2 million eye injuries and infections occur each year in the United States that leave civilians and military members with reduced or complete vision loss due to the lack of effective therapeutics. Severe ocular injuries and infections occur in varied settings including the home, workplace, and battlefields. In this review, we discuss the potential of developing antimicrobial peptides (AMPs) as therapeutics for the treatment of corneal wounds and infections for which the current treatment options are inadequate.

Recent Advances: Standard-of-care employs the use of fluorescein dye for the diagnosis of ocular defects and is followed by the use of antibiotics and/or steroids to treat the infection and reduce inflammation. Recent advances for treating corneal wounds include the development of amniotic membrane therapies, wound chambers, and drug-loaded hydrogels. In this review, we will discuss an innovative approach using AMPs with the dual effect of promoting corneal wound healing and clearing infections.

Critical Issues: An important aspect of treating ocular injuries is that treatments need to be effective and administered expeditiously. This is especially important for injuries that occur during combat and in individuals who demonstrate delayed wound healing. To overcome gaps in current treatment modalities, bioactive peptides based on naturally occurring cationic antimicrobial proteins are being investigated as new therapeutics.

Future Directions: The development of new therapeutics that can treat ocular infections and promote corneal wound healing, including the healing of persistent corneal epithelial defects, would be of great clinical benefit.

Keywords: bioactive peptides, wound healing, cornea, CAP37, infection, neutrophil

\section{SCOPE AND SIGNIFICANCE}

IT Is ESTIMATED that 2.4 million eye injuries occur each year in the United States. According to Prevent Blindness ${ }^{\circledR}, 90 \%$ of these ocular injuries are preventable, but lack of compliance in using protective eyewear makes prevention difficult. The most serious sequelae are encountered as a result of deep or penetrating injuries and when

(c) Gina L. Griffith et al., 2017; Published by Mary Ann Liebert, Inc. This article is available under the Creative Commons License CC-BY-NC (http://creativecommons.org/licenses/by-nc/4.0). This license permits non-commercial use, distribution and reproduction in any medium, provided the original work is properly cited. Permission only needs to be obtained for commercial use and can be done via RightsLink.

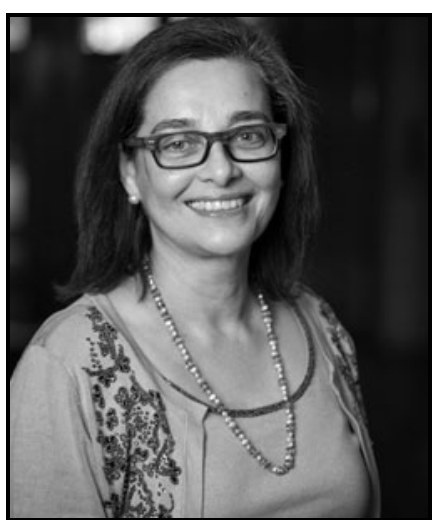

H. Anne Pereira, PhD

Submitted for publication November 4, 2016. Accepted in revised form Januray 30, 2017 *Correspondence: Department of Pharmaceutical Sciences, University of Oklahoma Health Sciences Center, $1110 \mathrm{~N}$. Stonewall Avenue, CPB 329, Oklahoma City, OK 73117

(e-mail: anne-pereira@ouhsc.edu). 
wounds fail to heal appropriately. These injuries may result in vision loss from scarring, secondary infection, require therapeutic intervention, and often result in poor outcomes. ${ }^{1}$ We propose the use of dual activity peptides as potential therapeutics to fulfill this unmet medical need.

\section{TRANSLATIONAL RELEVANCE}

While many ocular injuries heal naturally, serious ocular injuries require prompt treatment to prevent the onset of infection and decrease the risk of complications including scar formation. ${ }^{1}$ Current therapies are limited and involve anesthetic and antibiotic drops, ${ }^{1}$ which unfortunately have modest effect on healing, may have deleterious effects, and are ineffective at eradicating antibioticresistant pathogens. The ideal drug would be an antimicrobial that promotes corneal wound healing. Translational research including in vitro and in vivo proofs of concept studies have led to the identification of multifunctional bioactive peptides providing strong evidence that these peptides have potential for clinical development.

\section{CLINICAL RELEVANCE}

While most corneal wounds and abrasions require no intervention, $10 \%-20 \%$ of the 2,000 workrelated ocular injuries occurring each day in the United States result in temporary or permanent vision loss according to Prevent Blindness. In individuals with persistent corneal epithelial defects (PCEDs), there is a high risk for infection or further injury that results in permanent vision loss due to corneal scarring, infection, neovascularization, and incomplete wound healing. ${ }^{1}$ To effectively resolve the adverse clinical presentation of PCEDs, we discuss the potential therapeutic value of antimicrobial proteins and peptides.

\section{DISCUSSION OF FINDINGS AND RELEVANT LITERATURE}

\section{Antimicrobial peptides}

In the field of corneal wound healing and treatment of corneal infections, a significant line of research has emerged involving the exploitation of natural, endogenous antimicrobial peptides (AMPs). ${ }^{2,3}$ Many AMPs are produced and stored within the granules of polymorphonuclear neutrophils (PMN), the most abundant type of white blood cell. ${ }^{4}$ AMPs serve as one of the first lines of host defense against invading microorganisms. Research suggests that these proteins have the potential to be developed as broad spectrum, new, safer, and more effective antibiotics that are less prone to cause the development of antibiotic resistance. The latter is of concern when considering the treatment of microbial keratitis. ${ }^{3}$ AMPs are diverse in size and sequence, but they all have domains of amphipathic conformations with regions of hydrophobic amino acids and cationic polar domains. ${ }^{5}$ This common structural feature confers AMPs the ability to bind and disrupt the negatively charged lipid membranes of microorganisms leading to bacterial cell death. ${ }^{6}$ Studies now suggest that AMPs can also translocate across the membrane and bind to intracellular targets such as DNA, which can lead to cell death. ${ }^{7,8}$ These different modalities of attack (membrane permeabilization and intracellular effects) are of specific importance when considering potential antibiotic resistance to AMPs. The nonspecific potent killing mechanism involving membrane permeabilization may explain the broad spectrum activity and why there are limited opportunities for the organism to develop resistance mechanisms. ${ }^{9,10}$ Specificity for Grampositive or for Gram-negative bacteria has been described for certain AMPs. This specificity is likely due to the lipid composition of the outer bacterial membrane, determined by the presence or absence of lipopolysaccharide (LPS) in Gramnegative bacteria and lipoteichoic acids (LTA) in Gram-positive bacteria. ${ }^{6}$ LPS and LTA in the membranes of bacteria confer an additional negative charge to the membrane. ${ }^{11}$ The cationic charge of AMPs facilitates the selectivity for the negatively charged microbial cytoplasmic membranes versus zwitterionic or dipolar ions in mammalian membranes, ${ }^{11}$ which allows AMPs to specifically target bacterial cells rather than host cells.

\section{Additional properties of AMPs}

While AMPs are well known to have antimicrobial properties, more recently, it has been established that AMPs also have immunomodulatory properties on host cells. ${ }^{12}$ Studies have indicated that there is a delay in corneal epithelial wound healing when proteins essential for neutrophil extravasation into the tissue are not present. ${ }^{13,14}$ Studies performed in mice with antibody-induced neutropenia $^{15}$ support the concept that components found within the granules of neutrophils such as the cationic antimicrobial protein of $37 \mathrm{kDa}$ (CAP37, also referred to as azurocidin), the $\alpha$ - and $\beta$-defensins, the cathelicidin LL-37, and the bactericidal permeability-increasing protein (BPI, also referred to as CAP57), may be essential in facilitating corneal epithelial wound healing. Neutrophils, the first leukocytes recruited to sites of inflammation and tissue injury, release their 
granule contents after emigrating from the blood vessels to the site of injury. ${ }^{16}$ The contents of these granules include specific AMPs that provide the first line of defense against infection. ${ }^{17}$ It is now known that these AMPs, in addition to killing the invading pathogens, are able to modulate functions of host cells that regulate innate immunity. ${ }^{18}$ High amounts of these host defense peptides and proteins have been found at sites of inflammation and infection, but neutrophils may not be the only source of AMPs. It has been shown that AMPs can be induced and expressed in cells other than neutrophils. Expression of endogenous antimicrobial agents such as CAP37 and LL-37 has been observed in the dermis of animals in models of wound healing. ${ }^{15,19,20}$ Furthermore, CAP37 has been shown to contribute to the wound healing process by promoting the migration of monocytes to the wound site. ${ }^{19}$ Other studies have shown that CAP37 expression is induced in the corneal epithelium, stromal fibroblasts, ciliary epithelium, related limbus, ciliary vascular endothelium, and bulbar conjunctiva in rabbits with induced bacterial keratitis. ${ }^{21}$ CAP37 induces the migration of corneal epithelial cells and facilitates corneal epithelial wound healing. ${ }^{22-24}$ Further investigation indicates that chemotaxis may be mediated by a $\mathrm{G}$ protein-coupled receptor (GPCR) activated by CAP37. ${ }^{23}$ In addition, in vitro and in vivo studies implicate CAP37 activation of the protein kinase C (PKC) signaling pathway in corneal wound healing. ${ }^{23}$ Based on these observations, it was proposed that in addition to their killing properties, AMPs including CAP37 might have a critical role in reepithelialization and wound healing. These studies have helped form the foundation for our hypothesis that AMPs may be ideal therapeutics for the treatment of certain corneal wounds and infections.

\section{Corneal epithelial wound healing and physiological role of AMPs}

As light enters the eye, it is first refracted through a transparent tissue known as the cornea. The light passes through the pupil and is further refracted by the lens before the image is projected on the retina. The cornea is imperative for refracting light as it enters the eye and is responsible for two-thirds of the eye's focusing power. The cornea is made up of five layers (Fig. 1). The outermost layer is the corneal epithelium. The corneal epithelium is comprised of three layers of cells: stratified corneal epithelial cells, wing cells, and basal columnar cells from the outside in respectively (Fig. 1). The Bowman's layer is situated immediately below the corneal epithelium, fol-

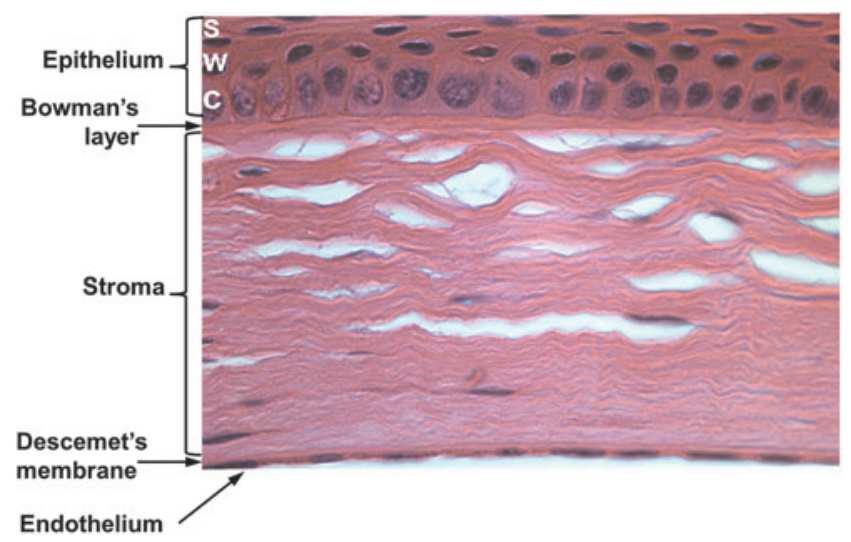

Figure 1. Structure of the cornea. The cornea is divided into five distinct layers: the epithelium anchored on the basement membrane, the Bowman's layer, stroma, Descemet's membrane, and the endothelium from the outside of the eye to the inside respectively. The corneal epithelium consists of three distinct layers of epithelial cells: the basal cells in the columnar layer (C) that lie on the basement membrane, wing cells (W), and the stratified epithelium (S) on the surface of the cornea. The Bowman's layer lies under the basement membrane and is composed mainly of collagen fibrils. Beyond the Bowman's layer is the stroma, which is comprised of water $(90 \%)$ and collagen with the main cell type being the keratocyte. The final two layers of the cornea are Descemet's membrane, also comprised mainly of collagen, and the endothelial layer, which helps the cornea to maintain its clarity. The histological section of the cornea was prepared from a paraffinembedded mouse eye and stained using hematoxylin and eosin. The sectioning and staining was performed by the Histology Core at the Dean McGee Eye Institute, Oklahoma City, OK. Image was taken using a $60 \times$ objective lens.

lowed by the stroma (which makes up $90 \%$ of the cornea), Descemet's membrane, and the endothelium. To function properly, all layers of the cornea must remain transparent, free of defects and vasculature. The outermost layer of the cornea, the corneal epithelium, provides the first line of defense against invading microorganisms and noxious stimuli. The surface of the corneal epithelium is continuously being bathed by the tear film which adheres to glycocalyx-secreting microvilli and microplicae on the squamous cells on the corneal surface. ${ }^{25}$ The tear film contains growth factors and AMPs that aid in protecting the cornea and facilitate wound healing. The major AMPs present at the ocular surface are defensins and LL-37. ${ }^{26}$ The $\alpha$-defensin proteins HNP-1, HNP-2, and HNP3 are found in neutrophils infiltrating the ocular surface and in the tear film. ${ }^{26}$ The $\beta$-defensin proteins human beta defensin-1 (hBD-1) and hBD-3 are constitutively expressed in the corneal and conjunctival epithelial cells, and hBD-2 is inducible in these cells by exposure to bacteria and LPS. ${ }^{26}$ LL-37 is found in infiltrating neutrophils and is inducible in corneal and conjunctival epithelial cells. ${ }^{26}$ These AMPs provide host defense against infection at the ocular surface, and through their 
interaction with epithelial cells may mediate cellular functions. Through the modulation of diverse cellular processes, certain AMPs contribute to the overall healing of the cornea.

Corneal epithelial wound healing is a complex process involving a number of cellular stages that include cell migration, proliferation, cell-matrix adhesion, and tissue remodeling. ${ }^{1}$ AMPs and proteins such as CAP37, LL-37, and the defensins have been shown to be present on the ocular surface and studies have demonstrated their role in the modulation of essential processes in corneal epithelial wound healing including epithelial cell migration, ${ }^{22}$ proliferation, ${ }^{27}$ and production of cytokines and adhesion molecules as shown in Table 1. ${ }^{19,27-29}$ Corneal epithelial wound healing has been described by some to occur in three ${ }^{30,31}$ and by others in four ${ }^{32}$ main phases. In this review, we describe the process as involving the following four overlapping phases (Fig. 2): lag or latent, mi-

Table 1. Summary of the role of antimicrobial peptide in corneal epithelial wound healing

\begin{tabular}{|c|c|c|}
\hline$A M P$ & Ocular Sources & $\begin{array}{c}\text { Role in Corneal Epithelial } \\
\text { Wound Healing }\end{array}$ \\
\hline \multicolumn{3}{|c|}{$\alpha$-Defensins } \\
\hline HNP-1 & Neutrophils (HNP-1, 2, 3) & \multirow{3}{*}{$\begin{array}{l}\text { Enhances fibronectin-induced } \\
\text { corneal epithelial cell migration } \\
\text { (HNP-1, in vitro) }\end{array}$} \\
\hline HNP-2 & Tear film (HNP-1, 2, 3) & \\
\hline HNP-3 & & \\
\hline \multicolumn{3}{|c|}{$\beta$-Defensins } \\
\hline hBD-1 & Corneal epithelial cells & \multirow{3}{*}{$\begin{array}{l}\text { Enhances fibronectin-induced } \\
\text { corneal epithelial cell migration } \\
\text { (hBD-2, in vitro) }\end{array}$} \\
\hline hBD-2 & Conjunctival epithelial cells & \\
\hline hBD-3 & $\begin{array}{l}\text { (Constitutive: hBD-1, hBD-3) } \\
\quad \text { (Inducible: hBD-2) }\end{array}$ & \\
\hline \multicolumn{3}{|c|}{ Cathelicidins } \\
\hline \multirow[t]{4}{*}{ LL-37 } & Neutrophils & $\begin{array}{l}\text { Migration of corneal epithelial } \\
\text { cells (in vitro) }\end{array}$ \\
\hline & Tear film & \multirow[t]{3}{*}{$\begin{array}{l}\text { Induces expression of IL-1 } \beta \text { and IL-8 } \\
\text { (in vitro) }\end{array}$} \\
\hline & $\begin{array}{l}\text { Corneal epithelial cells } \\
\text { (inducible) }\end{array}$ & \\
\hline & $\begin{array}{l}\text { Conjunctival epithelial } \\
\text { cells (inducible) }\end{array}$ & \\
\hline \multicolumn{3}{|c|}{ Cationic antimicrobial proteins } \\
\hline \multirow[t]{9}{*}{ CAP37 } & Neutrophils & $\begin{array}{l}\text { Migration of corneal epithelial cells } \\
\text { (in vitro) }\end{array}$ \\
\hline & Tear film & $\begin{array}{l}\text { Proliferation of corneal epithelial cells } \\
\text { (in vitro) }\end{array}$ \\
\hline & $\begin{array}{l}\text { Corneal epithelial cells } \\
\quad \text { (inducible) }\end{array}$ & $\begin{array}{l}\text { Production of cytokines } \\
\text { (in vitro, in vivo) }\end{array}$ \\
\hline & $\begin{array}{l}\text { Conjunctival epithelial cells } \\
\text { (inducible) }\end{array}$ & $\begin{array}{l}\text { Upregulates adhesion molecules } \\
\alpha 3 \text { and } \beta 1 \text { (in vitro) }\end{array}$ \\
\hline & Stromal fibroblasts (inducible) & \multirow{5}{*}{$\begin{array}{l}\text { Corneal epithelial wound healing } \\
\text { (in vivo) }\end{array}$} \\
\hline & Ciliary epithelium (inducible) & \\
\hline & Related limbus, (inducible) & \\
\hline & $\begin{array}{l}\text { Ciliary vascular endothelium } \\
\text { (inducible) }\end{array}$ & \\
\hline & Bulbar conjunctiva (inducible) & \\
\hline
\end{tabular}

AMP, antimicrobial peptide; IL-1 $\beta$, interleukin 1 beta; hBD-1, human beta defensin-1; CAP37, cationic antimicrobial protein of molecular weight $37 \mathrm{kDa}$. gration, proliferation, and the attachment or adhesion phases. ${ }^{33,34}$ These processes usually occur without complication during the first $48 \mathrm{~h}$ after injury. During the lag phase, which occurs within the first $6 \mathrm{~h}$ after corneal epithelial wounding, there is a reduction in the number of intercellular junctions and the hemidesmosome attachments between the epithelial cells and the basal membrane becomes weaker. ${ }^{32,33}$ During hours 1-4 of the lag phase, keratocyte apoptosis is the first stromal event that occurs as a result of the corneal epithelial injury. ${ }^{35}$ This event is marked by the apoptosis of keratocytes between a depth of 50 and $200 \mu \mathrm{m}$ in the anterior stroma. ${ }^{36}$ In the later stages of the lag phase, neutrophils begin to immigrate into the cornea through the ciliary and limbal vessels and up through the stroma into the cornea. Neutrophil influx into the cornea, however, has been shown not to peak until the migration phase or around $18 \mathrm{~h}$ postwounding. ${ }^{37}$ After the latent phase, the migration phase begins and continues through the first $36 \mathrm{~h}$ postinjury followed thereafter by the proliferation stage. During this phase, actin filaments assemble along the leading edge of cytoskeletal protrusions of the cells, referred to as lamellipodia and filopodia, which provide cytoskeletal support as the cell migrates. ${ }^{1,34}$ The columnar cells of the basal layer begin to loosen their attachments to the basement membrane and then migrate across the surface of the basement membrane. Until the end of the healing process, when the cells are anchored, they can easily be disrupted and wiped away. The basement membrane is a $50 \mathrm{~nm}$ sheet of fibers composed mainly of type IV collagen, laminin, heparin, proteoglycans, and smaller amounts of fibronectin and fibrillin. ${ }^{34}$ Integrins, which are transmembrane receptor proteins located on the cell surface, are responsible for forming focal contacts between cells and the extracellular matrix, ${ }^{38}$ and have been shown to bind components of the extracellular matrix including fibronectin, collagen, and laminin. In as little as one hour, proteins such as fibronectin, fibrinogen, and fibrin appear on the wound surface. ${ }^{33}$ CAP37 increases the expression of integrins $\alpha 3$ and $\beta 1$ on human corneal epithelial cells (HCEC) ${ }^{21}$ that allows corneal epithelial cells to specifically bind to extracellular matrix proteins such as fibronectin, ${ }^{39}$ laminin $5,{ }^{40,41}$ and laminin $10 .{ }^{42}$ These integrins may facilitate migration by providing focal contacts that the cells use to migrate. ${ }^{38}$ This is important as there is a possibility that the increase of integrins by AMPs and proteins may augment wound healing by mediating the cellular migration of HCECs during the migration phase of wound healing. For 


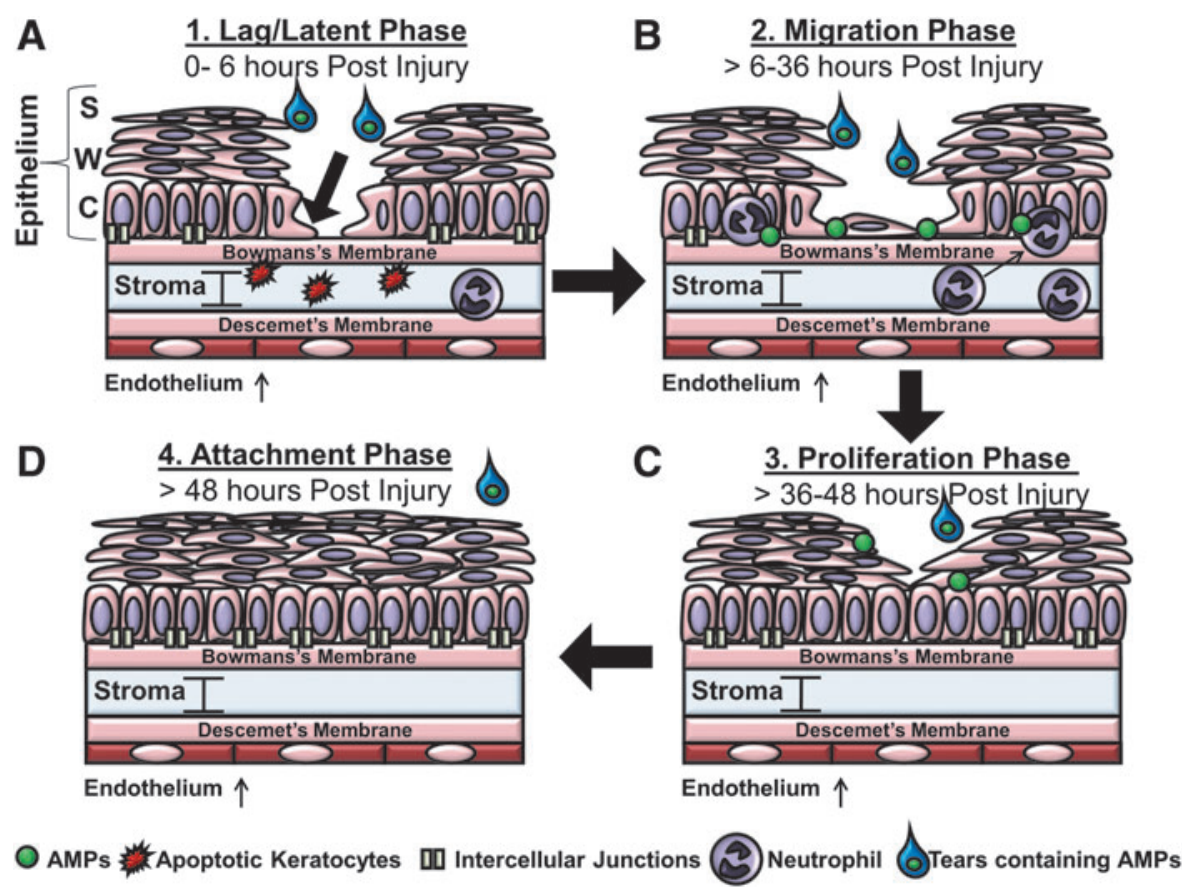

Figure 2. Four main stages of corneal epithelial wound healing. Corneal epithelial wound healing can be described to occur in four main phases (A-D). The initial lag or latent phase (A) of the wound healing process takes place during the first $6 \mathrm{~h}$ after injury. The lag or latent phase can be marked with a reduction in the number of intercellular junctions, the apoptosis of anterior keratocytes, and the beginning of some neutrophil infiltration into the cornea. During this phase, the basal epithelial cells (arrow) forming the columnar layer, also prepare to migrate. During the migration phase (B) occurring 6-36 h postinjury, the epithelial cells continue to migrate to close the gap and begin to adhere to the basement membrane. A primary wave (at $18 \mathrm{~h}$ ) and a secondary wave (at $30 \mathrm{~h}$ ) of neutrophils containing AMPs infiltrate into the stroma. The corneal epithelial cells produce AMPs such as CAP37 during this time. During the proliferation phase (C) occurring between 36 and $48 \mathrm{~h}$ postinjury, the basal epithelial cells from the columnar layer begin to proliferate before differentiating into wing and stratified corneal epithelial cells. The last phase in the process, the attachment phase (D), occurs $48 \mathrm{~h}$ postinjury as the cells firmly adhere back to the basement membrane and the number of intercellular junctions increase. The tear film is present throughout this process and is a known source of AMPs that may modulate the wound healing process. AMP, antimicrobial peptide; CAP37, cationic antimicrobial protein of molecular weight $37 \mathrm{kDa}$

example, LL-37 stimulates migration of cultured corneal epithelial cells and defensins HNP-1 and hBD-2 have been shown to enhance fibronectininduced corneal epithelial cell migration. ${ }^{43}$

It is also during the migration phase that neutrophils are thought to play an important role as the immigration of neutrophils into the cornea has been shown to peak in two main waves. The first around $18 \mathrm{~h}$ and the second around $30 \mathrm{~h}$ postcorneal epithelial abrasion. ${ }^{37}$ Upon reaching the cornea, neutrophils ingest and destroy microorganisms, clean up cellular debris of damaged cells, and also release the contents of the prepackaged azurophilic granules containing AMPs. The role of neutrophils in the wound healing process is twofold. The neutrophils not only clean up the debris of damaged cells, but also release AMPs that may contribute to wound healing. Previous studies have demonstrated that the depletion of either neutrophils or platelets in an in vivo animal model delays corneal wound healing. ${ }^{37}$ This suggests that neutrophils or platelets, both sources of AMPs, are required for normal healing. ${ }^{44,45}$ Because certain AMPs such as CAP37 induce cellular processes
(Fig. 2) that are important for wound healing, including migration, proliferation, and adhesion, ${ }^{24}$ we posit that it would be possible to use them as therapeutics to accelerate wound healing and simultaneously serve as an effective means of fighting an infection.

After migration, which leads to reepithelialization of the wound, the basal cells of the columnar layer must proliferate. In the final stage of wound healing, the basal cells, which are maintained by the proliferation and differentiation of stem cells residing in the limbus, ${ }^{46,47}$ continue to proliferate until the cornea reaches its normal thickness of $50 \mu \mathrm{m} .{ }^{48}$ CAP37 induces the proliferation of corneal epithelial cells, in contrast to LL-37 and defensins HNP-1 and hBD-2, which do not. During the proliferation phase, there is less movement of the epithelial cells. In the final phase of wound healing, the attachment phase, the epithelial layer firmly adheres to the basement membrane as the hemidesmosomes reform. ${ }^{49}$ The hemidesmosomes are an essential component in the attachment process. Without the hemidesmosomes, new epithelium will fail to firmly adhere to the basement membrane and will continue to erode. ${ }^{50}$ 


\section{Current therapies for ocular injuries}

For $6 \%$ of military members who sustained ocular injuries in the Global War on Terror ${ }^{51}$ and Operations Iraqi and Enduring Freedom, ${ }^{52,53}$ the ocular protection available was insufficient to prevent ocular injuries. Most ocular injuries are the result of direct face blast injury, projectiles, explosive devices, lasers, chemicals, and environmental or biological hazards that may lead to long-term vision loss. Fifteen to twenty percent of military patients with facial burns also experience ocular injuries. Through June 2006, up to $13 \%$ of the United States military wounded in battle had ocular injuries with $19 \%$ of evacuations to Echelon III level combat support hospital in Iraq and Afghanistan due to ocular injury. ${ }^{54}$ For military members and civilians alike, these ocular injuries regardless of the cause can lead to permanent vision loss. ${ }^{55} \mathrm{Im}$ mediate treatments of ocular injuries are still rudimentary and involve the topical administration of prophylactic antibiotics and administration of anesthetics or steroids, which can complicate or delay wound healing. ${ }^{1}$ In cases of severe ocular infection, including corneal ulcers and bacterial keratitis, current treatments may include antibiotic drops as frequently as every $5 \mathrm{~min}$ for the first five doses followed by a drop every $30 \mathrm{~min}$ for $6 \mathrm{~h}$. After the first $6 \mathrm{~h}$ of the treatment, the dose is decreased and drops are administered hourly. For the nearly 1 million individuals seeking treatments for ocular infections annually in the United States, ${ }^{56}$ this type of treatment regimen can be impractical, making patient compliance problematic. For the $71 \%$ of soldiers who experience injuries to their extremities, eye drops can be a challenge to administer. ${ }^{55}$ In the civilian population alone, ocular chemical burns represent up to $84 \%$ of ocular trauma emergency room visits. ${ }^{57}$ Chemical burns are treated initially by flushing the eye with at least $1 \mathrm{~L}$ of a saline solution and repeatedly testing the $\mathrm{pH}$ of the eye. The initial diagnosis of wounds usually involves visualizing sodium fluorescein dye, which binds to the corneal defect or injury and fluoresces bright yellow-green under cobalt blue light, from a slit lamp if one is available. In the case of chemical burns, the sodium fluorescein may not immediately stain the wound nor give an indication of wound depth. In such cases, the first line of treatment is to irrigate the wound with sterile saline or another appropriate ophthalmic solution such as Ringer's lactate. ${ }^{58}$ If the cornea is damaged by a foreign body, which account for $35 \%$ of the total eye injuries in civilians each year, ${ }^{59}$ it may be difficult to determine whether the cornea is perforated. In military members, diagnosis in the field may be especially difficult without the aid of a slit lamp. Furthermore, foreign bodies can leave rust marks in the cornea. ${ }^{60}$ It is important that rust marks be removed by an ophthalmologist within days of the injury followed by the administration of antibiotics until the defect has healed. ${ }^{55}$ In the case of the war fighter, an experienced ophthalmologist may not always be available. Therefore, the addition of therapeutics to effectively and prophylactically combat infection and minimize ocular damage before perforation occurs is essential.

Given the suboptimal early intervention strategies and drug delivery systems available to slow and/or stop the loss of vision after trauma, there is a need for the development of innovative ways to treat injuries early and effectively. There are currently no marketed products available for the medical need of promoting the healing process of these ocular corneal surface injuries for either military members or civilians. ${ }^{55}$ Therefore, the use of specific AMPs that can promote corneal wound healing while killing invading pathogens appears to be a promising therapeutic strategy.

\section{Ocular infection and antibiotic resistance}

According to the National Eye Institute (NEI), there are $\sim 250$ million corneal infections a year worldwide and $\sim 30,000$ cases of bacterial keratitis are reported annually in the United States. ${ }^{61}$ Bacterial keratitis is most often due to the microorganisms Staphylococcus aureus (25\% of cases) and Pseudomonas aeruginosa (17.5\% of cases). ${ }^{62}$ Antibiotic treatments, however, are not always effective especially against $S$. aureus due to its propensity to develop resistance to antibiotics. Resistance has rapidly developed to the most commonly used topical antibiotics such as the fluoroquinolones, ciprofloxacin, and ofloxacin. Methicillin-resistant $S$. aureus (MRSA) prevalence has increased from one out of five cases of bacterial keratitis caused by $S$. aureus to one out of three cases during the 20 years of the reported study. ${ }^{62}$ In addition, MRSA isolates have increased resistance to all tested antibiotics, including ciprofloxacin and ofloxacin, in comparison to methicillinsensitive $S$. aureus. ${ }^{62}$ In the case of bacterial keratitis due to multiresistant MRSA, vancomycin is the first choice of treatment. ${ }^{62}$ However, vancomycin is not ideal due to its toxicity, short half-life, cost, and need for refrigeration. ${ }^{62}$ Studies report that $P$. aeruginosa is still susceptible to ciprofloxacin, gentamicin, and cephalosporins, but as their clinical use increases, resistance appears to be rising. ${ }^{63}$ Rapid treatment is required for even the less-threatening cases of bacterial keratitis and $P$. aeruginosa corneal ulcers are more severe and more difficult to treat than other 
bacterial corneal ulcers. ${ }^{64}$ Studies suggest that while individuals should be tested for resistant strains to determine the proper treatment, treatment should be rapid, thus economic and time constraints often make these microbiologic studies impractical. ${ }^{63} \mathrm{An}$ tibiotic resistance of pathogenic bacteria is not new and has been a rising concern over the past three decades. To increase awareness of the threat that antibiotic resistance poses and to encourage immediate action to address the threat, the 2013 report, Antibiotic Resistance Threats in the United States, was recently published by the U.S. Centers for Disease Control and Prevention. As stated in this report, when first-line and then second-line antibiotic treatment options are limited by resistance or are unavailable, healthcare providers are forced to use antibiotics that may be more toxic to the patient and frequently more expensive and less effective. The lack of antibiotic therapeutics to treat these infections means that there are few alternatives for those experiencing ocular infections that may result in blindness. The use of AMPs, especially because of their nonspecific bactericidal mechanisms, appears to be a promising strategy to kill resistant and multiresistant pathogens and limit the development of additional resistance. In addition, their broad spectrum activity could make them particularly useful as initial therapy.

\section{Bioactive peptides based on CAP37}

Since its first partial purification from PMN cytoplasmic granules and the establishment of its antibacterial activity, ${ }^{17}$ the protein CAP37 (also called azurocidin) and its encoding gene (AZU1) have been sequenced. ${ }^{5,65-68}$ CAP37 is closely related to other neutrophil granule proteins. It shares $43 \%$ identity with neutrophil elastase and proteinase 3 , and $34 \%$ identity with cathepsin G. All three belong to the chymotrypsin-like family of serine proteases. ${ }^{65}$ By the definition of this family of serine proteases, the catalytic triad is composed of three conserved residues: histidine-47, asparagine102, and serine-195, in which serine serves as the nucleophilic or electron-donor amino acid in the active site. ${ }^{69}$ However, unlike all the other serine proteases in this family, the catalytic triad of CAP37 is formed by serine-41, asparagine-89, and glycine-175. This led many to believe that CAP37 lacked enzymatic protease activity. ${ }^{70,71}$ Recent studies, however, have suggested that CAP37 has protease activity on substrates such as insulin-like growth factor-binding protein-1, -2 , and $-4 .^{72}$

Initial structure-function studies were conducted to delineate the antimicrobial domains within the 222 amino acid sequence of the native CAP37 mol- ecule with the primary goal of developing bioactive peptides for treating Gram-negative infections. Unlike conventional antibiotics, the antimicrobial mechanism of action of bioactive peptides derived from CAP37, much like the defensins,${ }^{73}$ is believed to be a nonspecific electrostatic interaction leading to the disruption of the bacterial membrane. ${ }^{74}$ As previously mentioned, the development of antimicrobial resistance against such AMPs is expected to be low.

CAP37-derived peptides were synthesized to be $\sim 25$ amino acids long with at least two to five amino acids overlap at each end, and spanning the CAP37 molecule. The peptides were designated by the amino acid number and are referred to as peptide 1-25, 20-44, 38-53, 43-53, 72-80, 95-122, 102-122, 113-122, 120-146, 140-165, 198-202, 180-202, and 197-222. ${ }^{74}$ Each peptide was studied for antimicrobial and chemotactic activities. Peptide 20-44 (Figs. 3 and 4) was determined to have strong antimicrobial properties ${ }^{74}$ and peptide 95 122 (Figs. 3 and 4) was found to induce migration of corneal epithelial cells (data not shown).

Peptide 20-44 is of particular importance due to its strong antimicrobial activity against Gramnegative pathogens such as $P$. aeruginosa, Acinetobacter baumannii, Escherichia coli, and Salmonella Typhimurium. ${ }^{71}$ The peptide was found to be more effective than the full-length native CAP37 protein at killing the Gram-positive bacteria $S$. aureus and Enterococcus faecalis. ${ }^{74,75}$ Peptide 20 44 contains two cysteines at positions 26 and 42 (Fig. 3) that could potentially form a disulfide bond. Disulfide bonds are crucial for the killing activity of certain AMPs. To test the importance of disulfide bond formation on the activity of peptide 20-44, analogs of the CAP37 peptide were synthesized.

\footnotetext{
$20-04$ IVGGRKARPRQFPFLASIQNQGRHFCGGALIHARFVMTAASCFQSQ

NPGVSTVVLGAYDLRRRERQSRQTFSISSMSENGYDPQQNLNDLML LQLDREANLTSSVTILPLPLQNATVEAGTRCOVAGWGSORSGGRLS RFPRFVNVTVTPEDQCRPNNVCTGVLTRRGGICNGDGGTPLVCEGL AHGVASFSLGPCGRGPDFFTRVALFRDWIDGVLNNPGP
}

Figure 3. Bioactive peptides based on CAP37. Amino acid sequence of the CAP37 molecule and bioactive peptides are indicated. Structurefunction studies have revealed that the dual functionality of the CAP37 protein is conferred by specific domains of the molecule. Amino acid residues 20 through 44 (red) have been found to exhibit antimicrobial properties and a domain between amino acid residues 95 and 122 (yellow) has been shown to mediate chemotaxis of corneal epithelial cells. Dual activity (antimicrobial and chemotactic) was uncovered and shown to reside in domain 120 through 146 (underlined) of the CAP37 molecule. This dual activity was conferred when the amino acid of the native sequence was changed from 0131 to W131 and from R132 to H132 (shown in blue). 


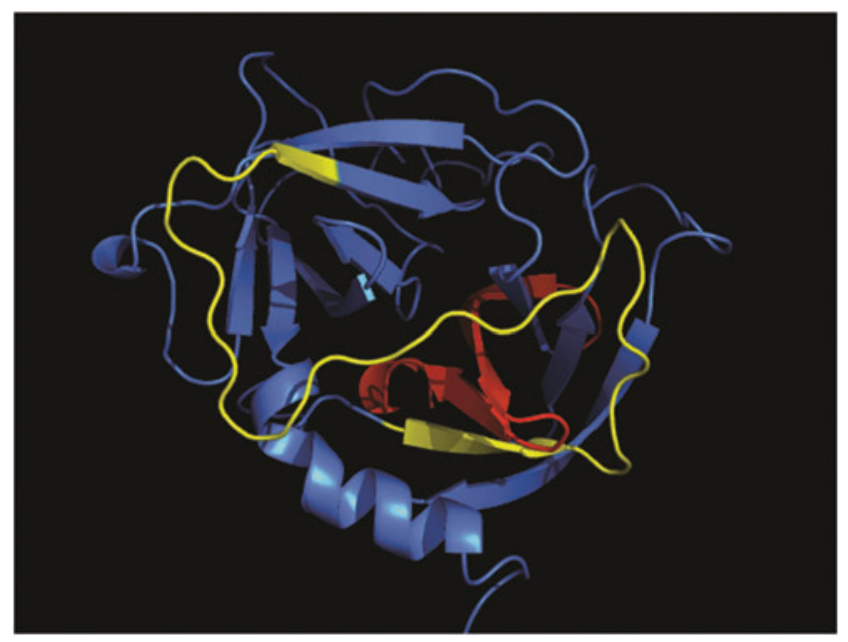

Figure 4. Structure of the CAP37 molecule and localization of the antimicrobial and chemotactic domains. The antimicrobial domain has been shown to lie between residues 20 and 44 of the native CAP37 protein (indicated in red). This domain is located internally. The chemotactic domain lies between residues 95-122 (indicated in yellow). A synthetic peptide based on this amino acid sequence has been shown to mediate corneal epithelial cells chemotaxis. The domain is located on the outer loops of the native CAP37. Image was created using PyMol.

Each cysteine was changed to a serine and the killing activity of the peptides with the substituted residues was tested. ${ }^{67}$ The presence of a disulfide bond did not appear to be critical for the activity of peptide 20-44 since peptides that contain both or only one cysteine residue all had similar antimicrobial properties. ${ }^{76}$

Perhaps just as important as the antimicrobial properties of 20-44 is the ability of this peptide to bind and neutralize LPS. In the case of Gramnegative bacteria, LPS is a major virulence factor that can activate the inflammatory cytokine cascade leading to the production of mediators such as tumor necrosis factor alpha (TNF- $\alpha)$, which can exacerbate an inflammatory response. ${ }^{77}$ The production of TNF- $\alpha$ by macrophages as a result of nuclear factor kappa $\mathrm{B}(\mathrm{NF}-\kappa \mathrm{B})$ activation is triggered by the binding of LPS to the LPS binding protein, which leads to the binding of LPS to CD$14 .^{78}$ The LPS-CD14 complex then binds to an immune receptor on cells known as toll-like receptor 4 (TLR4). ${ }^{78}$ Upon binding of LPS to TLR4, the inhibitor of kappa B ( $/ \kappa \mathrm{B})$ kinase (IKK) is activated and phosphorylates inhibitor kappa B alpha $(\mathrm{I} \kappa \mathrm{B} \alpha)$. The phosphorylation of $\mathrm{I} \kappa \mathrm{B} \alpha$ by IKK leads to the degradation of $\mathrm{I} \kappa \mathrm{B} \alpha{ }^{79} \mathrm{As}$ a result, NF- $\kappa \mathrm{B}$ is released from $\mathrm{I} \kappa \mathrm{B} \alpha$ and moves from the cytosol into the nucleus ${ }^{79}$ where it acts as a transcription factor leading to the production of inflammatory cytokines, including TNF- $\alpha .{ }^{80}$ In a recent study, ${ }^{81}$ the secretome of common bacteria causing keratitis, including $P$. aeruginosa and $S$. aureus, was found to inhibit corneal wound healing. Shed LPS found in the secretome was identified as the culprit by genetic studies. Genes involved in LPS biosynthesis and controlling the structure of the LPS core were shown by mutation and complementation studies to play a role in the LPS inhibition of corneal epithelial cells migration and inhibition of corneal wound healing. LL-37, ${ }^{78}$ CAP37, ${ }^{82}$ BPI,${ }^{83}$ magainin, ${ }^{78}$ and the cecropin:melittin hybrid cationic AMP (CP 29) have all been shown to bind and neutralize LPS. Peptide 20-44 when administered intravenously prevents endotoxin-induced responses in conscious rats. ${ }^{82}$ As shown in Fig. 5, in vitro studies from our laboratory indicate that the neutralization of LPS by peptide 20-44 blocks the phosphorylation of $\mathrm{I} \kappa \mathrm{B} \alpha$ (Fig. 5A). As a result, the production of the inflammatory cytokine TNF- $\alpha$, which leads to endotoxininduced responses, is inhibited (Fig. 5B). ${ }^{78}$ This property of certain AMPs to bind and neutralize LPS provides the additional benefit of blocking the LPSinduced inhibition of corneal wound healing. Unlike peptide 20-44, studies have shown that treatment with the full-length CAP37 protein does not prevent the LPS activation of human monocytes and macrophages and the release of TNF- $\alpha .{ }^{85,86}$ The generation of peptides that can mediate antimicrobial activity and can also neutralize LPS could prove to be a great advantage over the utilization of the entire protein.

Of the CAP37-derived peptides tested in the Boyden Chemotaxis chamber assay, peptide 95122 was found to induce the strongest chemotactic activity in corneal epithelial cells (data not shown). The hypothesis that the 95-122 region is the main chemotactic domain of CAP37 was supported by an experiment showing the complete inhibition of fulllength CAP37-induced chemotactic activity, when using a monoclonal antibody that specifically recognizes the 95-122 region of the protein (data not shown). Interestingly, the chemotactic activity of peptide 95-122 could also be fully inactivated with an antibody. As shown in Fig. 6, peptide 95-122 by itself has significant chemotactic activity on corneal epithelial cells when used at $10^{-6} \mathrm{M}$. This activity was completely inhibited by a polyclonal antibody produced in rabbits, immunized with this peptide. Since residues 95-122 are located on the outer surface of the native CAP37 protein (Fig. 4), it is reasonable to hypothesize that this region of the protein binds to a membrane receptor, possibly a GPCR as suggested by our previous studies. ${ }^{24}$ This region could thus mediate the effects of CAP37 on host cells, an idea that is further supported by evidence showing that peptide 95-122 can modulate the PKC signaling pathway in endothelial cells. ${ }^{87}$ 

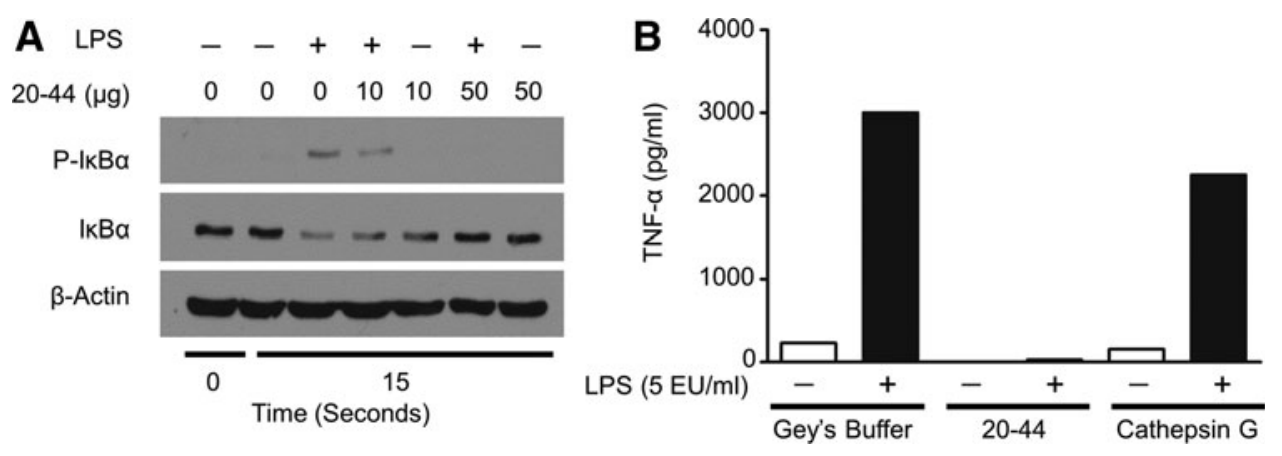

Figure 5. Neutralization of LPS by CAP37 Peptide 20-44. (A) RAW 264.7 mouse macrophages were treated with Escherichia coli endotoxin (10 ng/mL, 30 EU/ $\mathrm{mL}$ ) for $15 \mathrm{~min}$, with or without peptide 20-44 (10 and $50 \mu \mathrm{g} / \mathrm{mL})$. Cell lysates were prepared and assayed by western blot analysis for phosphorylated $\mathrm{I} \kappa \mathrm{B} \alpha(\mathrm{P}$ $\mathrm{I}_{\kappa} \mathrm{B} \alpha$, Ser 32) and total $\mathrm{I} \kappa \mathrm{B} \alpha . \beta$-actin was utilized as a loading control. Peptide 20-44 decreased phosphorylation of $\mathrm{I}_{\kappa} \mathrm{B} \alpha$ as seen in lane 4 and lane 6. (B) RAW 264.7 mouse macrophages were treated with Pseudomonas aeruginosa endotoxin $(5 \mathrm{EU} / \mathrm{mL})$, peptide $20-44(150 \mu \mathrm{g} / \mathrm{mL})$, cathepsin G peptide control $(150 \mu \mathrm{g} /$ $\mathrm{mL}$ ), or Gey's buffer (vehicle control). Supernatants were collected at $3 \mathrm{~h}$ post treatment and assayed for TNF- $\alpha$ by enzyme-linked immunosorbent assay. Peptide 20-44 blocked the endotoxin-induced release of TNF- $\alpha$, when compared to the release of TNF- $\alpha$ in the absence of peptide or in the presence of cathepsin $\mathrm{G}$ peptide. $I_{\kappa} \mathrm{B} \alpha$, inhibitor kappa B alpha; LPS, lipopolysaccharide; TNF- $\alpha$, tumor necrosis factor alpha.

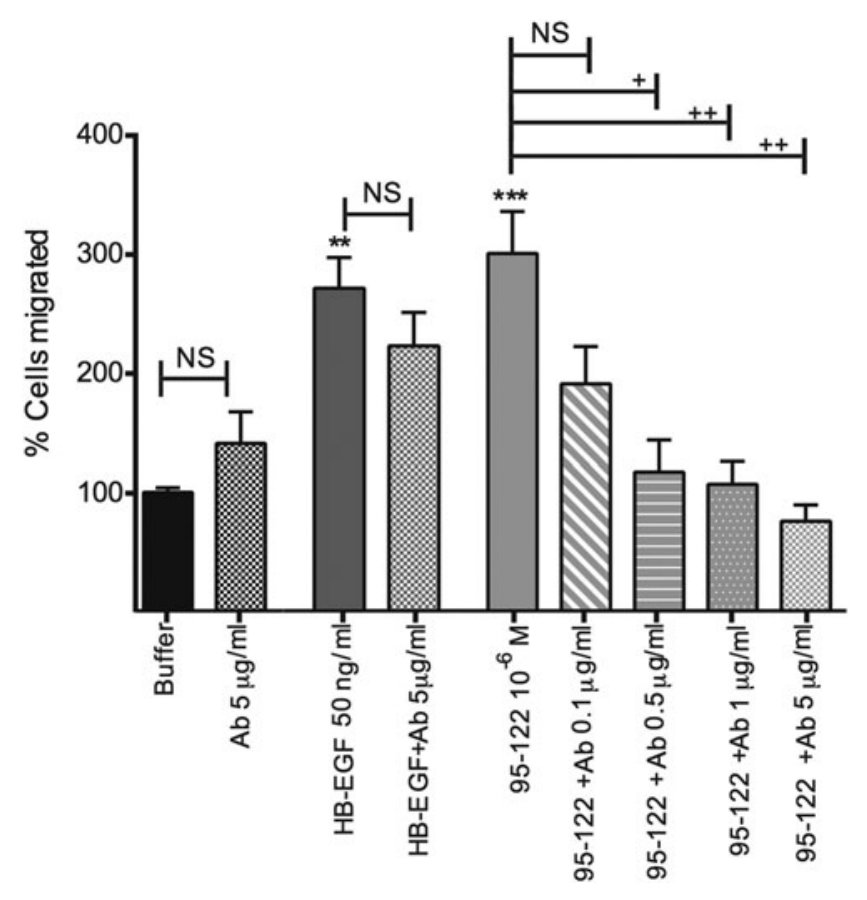

Figure 6. Chemotactic properties of peptide 95-122. Peptide 95-122 has significant chemotactic activity on corneal epithelial cells. Cell migration was induced by $50 \mathrm{ng} / \mathrm{mL}$ of HB-EGF (used as control) or $10^{-6} \mathrm{M}$ of peptide 95-122, tested in absence or in presence of a polyclonal antibody $(0.1,0.5,1$, and $5 \mu \mathrm{g} / \mathrm{mL}$ ) produced in rabbits by immunization with this peptide. Controls included antibody at $5 \mu \mathrm{g} / \mathrm{mL}$ on its own and HB-EGF with antibody at $5 \mu \mathrm{g} / \mathrm{mL}$. The results were plotted as percent cells migrated, compared to buffer control arbitrarily set as $100 \%$. Average and SEM were derived from three independent experiments, each done in triplicate. Results were analyzed using nonparametric one-way analysis of variance (Kruskal-Wallis test) followed by Dunn's multiple comparisons. ${ }^{* *}$ indicates $p<0.01$ and ${ }^{* * *}$ indicates $p<0.001$ when compared to buffer control. + indicates $p<0.05$ and ++ indicates $p<0.01$ when comparing with and without antibody. NS, not significant; HB-EGF, heparin binding-epidermal growth factor; SEM, standard error of the mean.
As discussed earlier, the chemotactic activity of the full-length CAP37 on corneal epithelial cells translated in vitro and in vivo into an acceleration of corneal wound closure. ${ }^{24}$ Similarly, we found that peptide 95-122 significantly facilitated corneal wound healing in mouse (data not shown). To determine the mechanism of action of peptide 95122 in vivo, we examined the temporal expression of cytokines in the cornea, in response to peptide 95-122. For these studies, the peptide was injected intrastromally, and the corneas removed at given time points and analyzed on a 32 cytokine multiplex system. Injection of peptide 95-122 at a final concentration of $10^{-4}, 10^{-5}$, and $10^{-6} \mathrm{M}$ resulted in significant increases in the expression of interferon gamma (IFN- $\gamma$ ) (Fig. 7A), interleukin 7 (IL-7) (Fig. 7B), macrophage inflammatory protein 1 alpha (MIP1- $\alpha$ ) also known as CCL3 (Fig. 7C), and interleukin 15 (IL-15) (Fig. 7D) at $24 \mathrm{~h}$ when compared to saline-injected controls. At $48 \mathrm{~h}$, expression levels of all four cytokines had returned back to saline-injected control levels. IFN- $\gamma$ is a cytokine produced by $\mathrm{T}$ helper type 1 cells, cytotoxic T cells, natural killer cells, monocytes/macrophages, and other antigen-presenting cells ${ }^{88,89}$ with the ability to inhibit the replication of viruses. ${ }^{90,91}$ While the chronic production of cytokines such as IFN- $\gamma$, has been associated with pathologies such as dry eye, ${ }^{92}$ the transient production of IFN- $\gamma$ in response to peptide 95-122 indicates that this peptide could modulate responses that protect the eye from infection. IL-7 is a cytokine produced by a number of cells including epithelial cells ${ }^{93}$ and a well-known promoter of $\mathrm{T}$ cell development. ${ }^{94}$ MIP1- $\alpha$ is a 

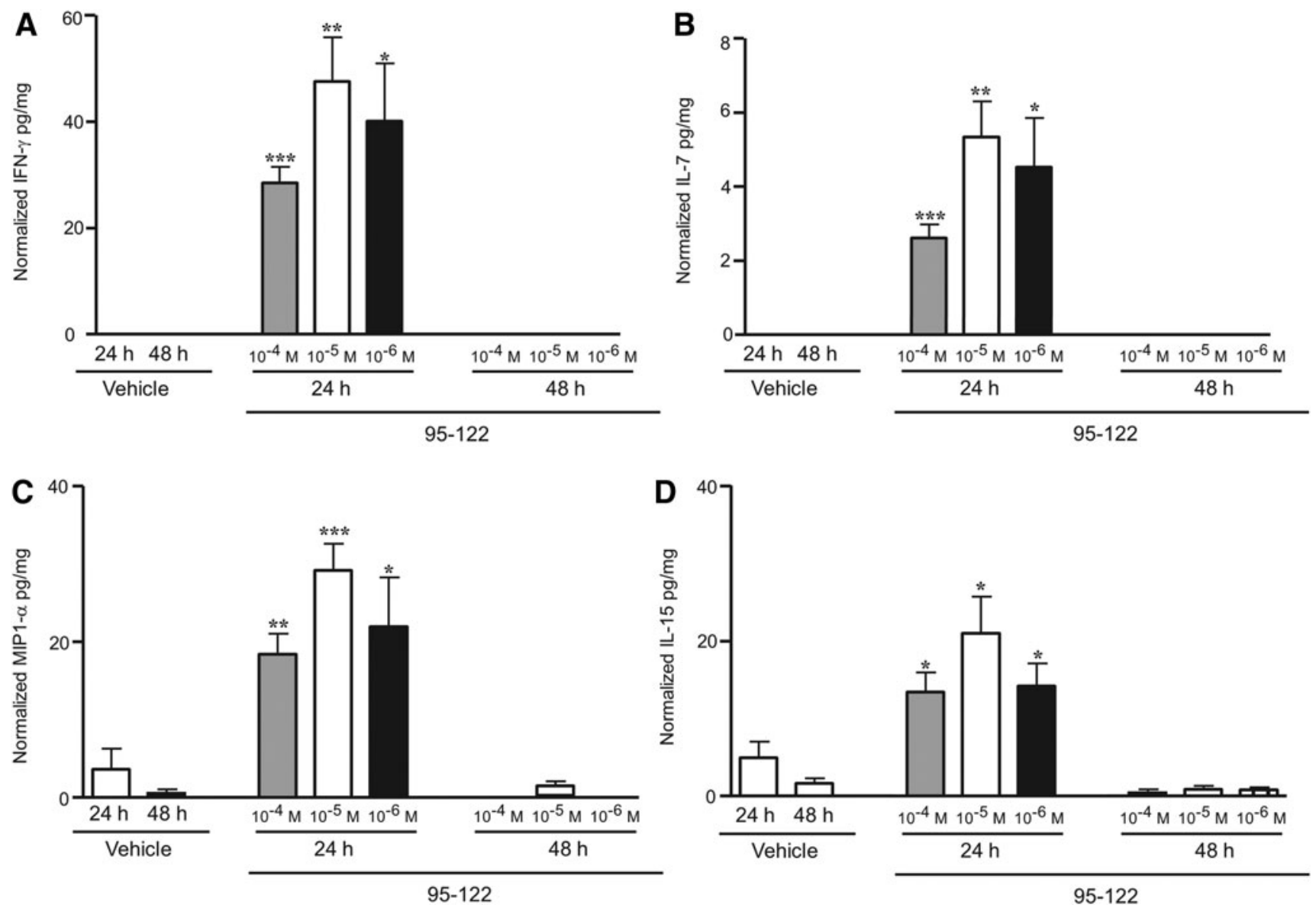

Figure 7. Peptide 95-122 significantly increases IFN- $\gamma$, IL-7, MIP1- $\alpha$, and IL-15. The study involved intrastromal injections into mouse eyes of $0.5 \mu$ of peptide 95-122 at final concentrations of $10^{-4}, 10^{-5}$, and $10^{-6} \mathrm{M}$. Corneas were collected and flash frozen at 24 and $48 \mathrm{~h}$. Corneal lysates were analyzed for cytokines using the Milliplex ${ }^{\circledR}$ MAP mouse cytokine assay for IFN- $\gamma$ (A), IL-7 (B), MIP1- $\alpha$ (C), and IL-15 (D). The means of five independent experimental values are shown \pm SEM. ${ }^{* * *} p<0.001,{ }^{* *} p<0.01,{ }^{*} p<0.05$ by unpaired $t$-test as compared to vehicle-treated controls. All animal studies were conducted according to institutional guidelines and the ARVO Statement for the Use of Animals in Ophthalmic and Vision Research. IL, interleukin; INF- $\gamma$, interferon gamma; MIP1- $\alpha$, macrophage inflammatory protein 1 alpha.

chemoattractant of macrophages, dendritic cells, and lymphocytes and is also produced by these cell types. ${ }^{95}$ IL-15 leads to morphological changes in neutrophils and is produced by activated $\mathrm{T}$ cells, monocytes/macrophages, and dendritic cells. ${ }^{96}$ IL15 has also been shown to increase the surface expression of CD11b ${ }^{97,98}$ on neutrophils and is essential in wound healing. ${ }^{4}$ Injection of a final concentration of $10^{-4}$ and $10^{-5} \mathrm{M}$ of peptide 95-122 significantly increased the expression of macrophage inflammatory protein 1 beta (MIP1- $\beta$ ) also known as CCL4 (Fig. 8A), interleukin 1 beta (IL-1 $\beta$ ) (Fig. 8B), keratinocyte chemoattractant (KC) (Fig. 8C), and granulocyte-macrophage colonystimulating factor (GM-CSF) (Fig. 8D) at $24 \mathrm{~h}$ when compared to corneas injected with saline only. The expression of MIP1- $\beta$ returned to low basal level at $48 \mathrm{~h}$. MIP1- $\beta$ is a chemoattractant of neutrophils, monocytes, and $\mathrm{T}$ cells and is also produced by these cells. ${ }^{99}$ This cytokine is highly related to and shares signaling pathways with MIP1- $\alpha .{ }^{99}$ IL-1 $\beta$ has been found in tears and has selective effects on corneal epithelial cell migration, adhesion, differentiation, and neutrophil immigration. IL-1 also upregulates IL-8, a homolog of the mouse cytokine $\mathrm{KC},{ }^{100,101}$ and a known promoter of neutrophil migration. The receptor for IL$1 \beta$ is expressed constitutively on corneal epithelial cells ${ }^{102}$ where it is considered a regulator of wound healing. ${ }^{103,104}$ The multifunctional role of IL-1 $\beta$ suggests that its increase by peptide 95-122 may help to facilitate wound healing and regulate other cytokines, such as KC, (IL-8 in humans), which are also involved in mediating neutrophil migration. LL-37 has been shown to induce expression of IL$1 \beta$ and IL-8 in cultured corneal epithelial cells. GM-CSF is also known to be a chemoattractant for neutrophils. ${ }^{105}$ While the exact role of these cytokines can be hypothesized, it is important to note that their functions in response to the peptide 

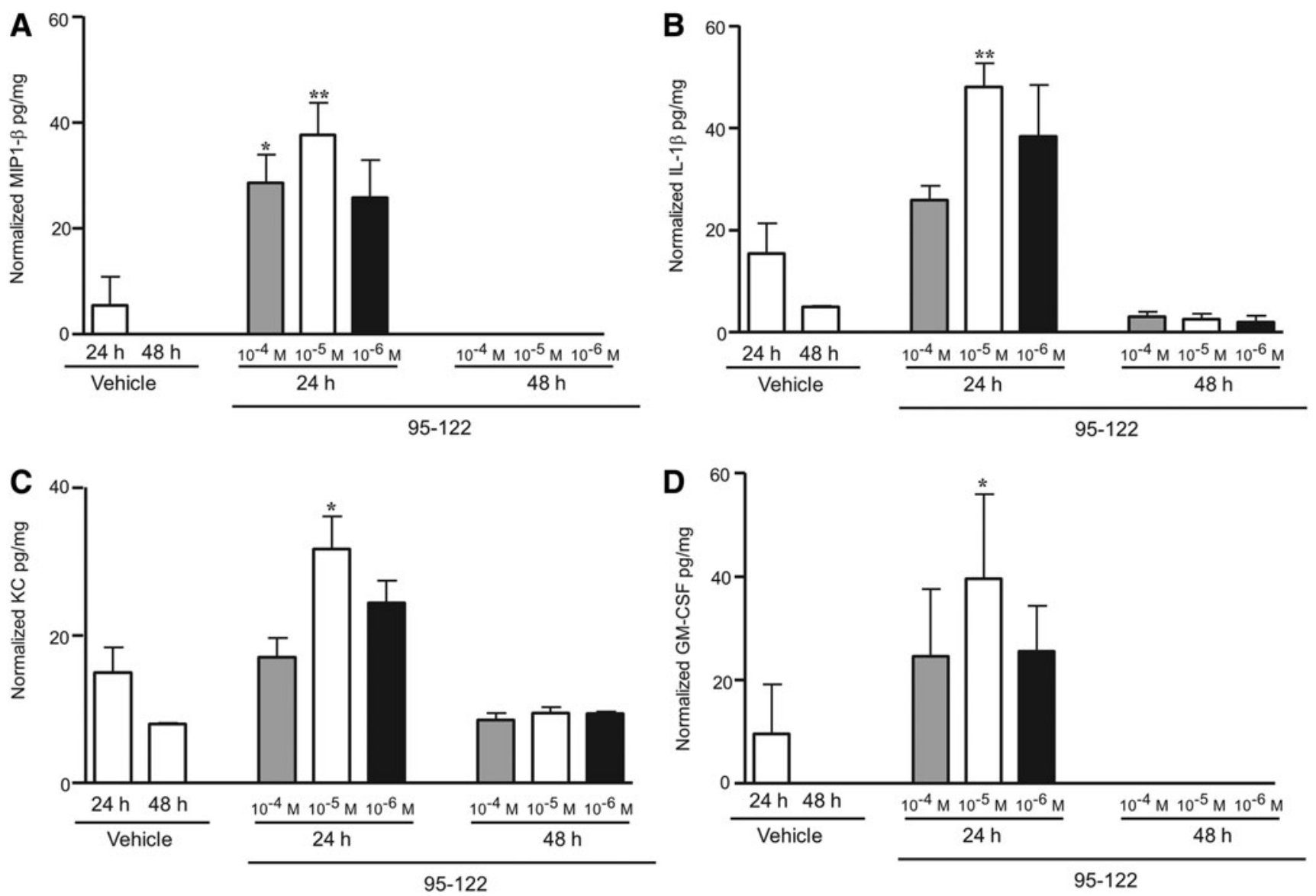

Figure 8. Peptide 95-122 significantly increases MIP1- $\beta, \mathrm{KC}, \mathrm{IL}-1 \beta$, and GM-CSF. As indicated in Fig. 7, the study involved intrastromal injection into mouse eyes with $0.5 \mu \mathrm{L}$ of peptide 95-122 at final concentrations of $10^{-4}, 10^{-5}$, and $10^{-6} \mathrm{M}$. Corneas were collected and flash frozen at 24 and $48 \mathrm{~h}$. Corneal lysates were analyzed for cytokines using the Milliplex MAP mouse cytokine assay for MIP1- $\beta$ (A), IL-1 $\beta$ (B), KC (C), and GM-CSF (D). ${ }^{* *} p<0.01,{ }^{*} p<0.05$ by unpaired $t$-test as compared to vehicle-treated controls. All animal studies were conducted according to institutional guidelines and the ARVO Statement for the Use of Animals in Ophthalmic and Vision Research. KC, keratinocyte chemoattractant; GM-CSF, granulocyte-macrophage colony-stimulating factor.

administration remain unclear and need to be elucidated in future studies.

In conclusion, intrastromal injection with CAP37derived 95-122 peptide leads to the increase in expression of cytokines that may work together in a concerted fashion to facilitate the healing of corneal wounds. No pathology was seen in association with the injection of peptide 95-122. Furthermore, all cytokines that were increased at $24 \mathrm{~h}$ had returned to basal levels $48 \mathrm{~h}$ after injection, indicating that the effect of the peptide had resolved by $48 \mathrm{~h}$ and posed no long-term adverse events.

Peptide 120-146 (Figs. 3, 9 and 10) was found to have some biological activity in our original antimicrobial screen but did not appear to have strong chemotactic activity for corneal epithelial cells. However, when it was discovered that CAP37 was induced in the cornea ${ }^{21}$ and that the induced sequence of corneal-derived CAP37 varied from neutrophil-derived CAP37 at one position (residue 132), the two variations of peptide 120-146 were synthesized. The neutrophil-derived sequence has an arginine at position 132 and the corneal-derived sequence has a histidine at position $132 .^{21}$ The reason for this substitution in the cornea is unknown. Both peptides comprise five positively charged residues and no negatively charged residues, so that the net charge is positive. Both peptides also contain 15 hydrophobic residues, out of the 26 total residues, which makes them strongly hydrophobic. These amphiphile properties were expected to confer antimicrobial activity to the peptides. The neutrophil-derived analog (120-146 QR) and corneal-derived analog (120-146 QH) displayed antimicrobial activities, although the effects were not dramatic. ${ }^{106}$ In further structure function studies, the hydrophilic glutamine residue (Q) at position 131 (Fig. 10) of peptides 120-146 QH and 120-146 QR was replaced with a hydrophobic tryptophan residue (W). This change dramatically increased the antimicrobial activity of the peptide against the Gramnegative pathogen $P$. aeruginosa. At the highest dose 


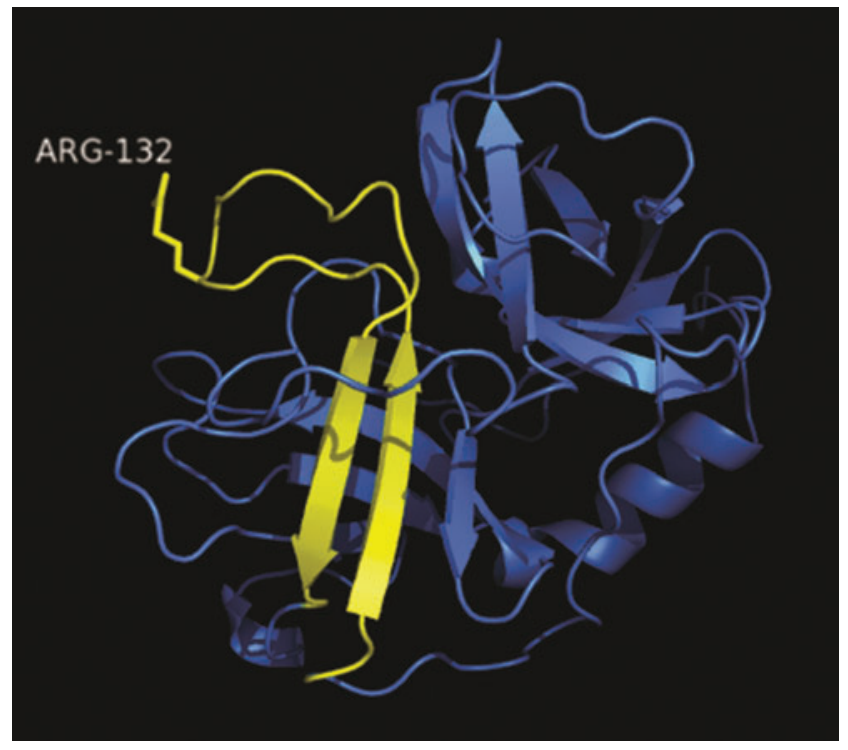

Figure 9. Structure of the CAP37 molecule and localization of domain 120 146. Domain 120-146 (indicated in yellow) consists of residues that are located on the surface loop and also internally in $\beta$-sheets. An arginine at position 132 (ARG132, as labeled and indicated in yellow) is present in neutrophil-derived CAP37. In CAP37 expressed in the corneal epithelium, however, the arginine at position 132 is replaced with a histidine. Image was created in PyMol.

tested, $5 \times 10^{-5} \mathrm{M}$, peptide $120-146 \mathrm{QH}$ and $120-146$ $\mathrm{QR}$ achieved a maximum of 1-2 log reduction in colony-forming unit/mL whereas peptides 120-146 $\mathrm{WH}$ and 120-146 WR achieved a 5.5 log reduction, killing $100 \%$ of the bacteria. ${ }^{106}$

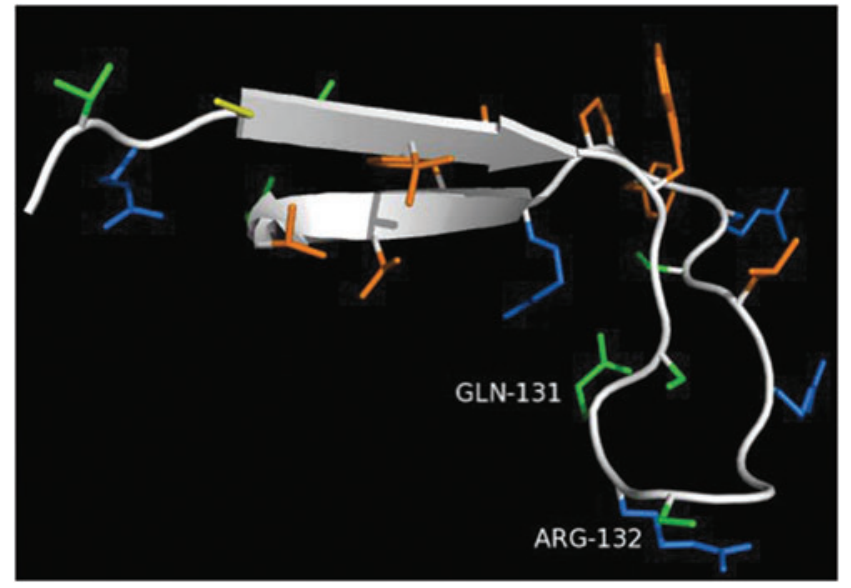

Figure 10. Structure of peptide with residues 120-146 QR of the native neutrophil CAP37 protein. The domain composed of amino acid residues 120-146 contains a beta sheet structure and forms a loop in the native structure. In the native sequence found in neutrophils, a glutamine is present at residue 131 (GLN-131) and an arginine residue at residue 132 (ARG-132). Cysteines are shown in yellow, polar residues in blue, hydrophobic residues in orange, and hydrophilic residues in green. Peptides 120-146 WR, 120-146 $\mathrm{QH}$, and 120-146 WH are not shown, but the variations occur at the same residues depicted, 131 and 132 . Given that it is unknown how these peptides behave in suspension, it is difficult to predict which orientation or rotamer the residues would exhibit. Image created using PyMol.
Furthermore, although the neutrophil version of this peptide (120-146 QR) did not induce chemotactic activity in corneal epithelial cells, the corneal version (120-146 QH), was chemotactic toward corneal epithelial cells. Further modification of the corneal version of this peptide into 120-146 WH did not alter the maximal chemotactic activity of the peptide. ${ }^{106}$ These structural manipulations have resulted in a peptide, 120$146 \mathrm{WH}$, which possesses dual antimicrobial and chemotactic activities. Additional studies established that peptide 120-146 WH could bind and inactivate LPS, clear a $P$. aeruginosa-induced corneal infection in vivo, and promote corneal wound healing in mouse. ${ }^{106}$

Collectively, these results place peptide 120-146 $\mathrm{WH}$ as an ideal candidate for therapeutic applications targeting corneal wounds and infections. Studies including further modifications of this peptide and optimization of its formulation and delivery are currently ongoing to increase solubility, stability, scalability, activity, and ease of delivery for therapeutic applications. Currently, there is no therapeutic on the market combining antimicrobial and wound healing activities for corneal injuries. Therefore, we believe that a dual activity peptide therapeutic based on 120-146 WH will address an unmet need in the treatment of corneal injuries.

\section{SUMMARY}

The increase in ocular injuries in recent military conflicts and in the civilian population has prompted the growing need for innovative ocular therapeutics. The lack of treatments currently available to treat ocular injuries, lack of compliance in the wearing of eye protection, and often the practicality of wearing eye protection have increased the need for new therapeutics to facilitate the healing of ocular injuries and infections. The rise of antibiotic-resistant infections has led to the search for naturally occurring antibiotics to which infectious agents are less likely to develop resistance. The ability to accelerate wound closure and healing without fibrosis would clearly be an added advantage. AMPs may provide a suitable solution to a growing problem. AMPs such as CAP37 are secreted by neutrophils and are also produced by the corneal epithelium in response to infection and wounding. These AMPs have the potential to be developed as future therapeutics to combat infection and promote wound healing. When utilized in conjunction with sustained delivery systems such as hydrogels, amniotic membrane, bandage 
contact lenses, and ocular wound chambers, AMPs could be utilized to effectively treat ocular wounds and infection. Peptides derived from these AMPs may provide for more efficacious antimicrobial therapeutics with the ability to specifically modulate wound healing.

\section{ACKNOWLEDGMENTS AND FUNDING SOURCES}

This project was supported by the following grants: Public Health Service Grants NIH/NEI 5R01EY015534 and 5U01AI075391 (H.A.P., PhD, PI), Molecular Basis of Immunity-KirschsteinNRSA NIH 5T32AI007633 (Madeleine Cunningham, PhD, PI), P30-Center Core Grant for Vision Research 5P30EY021725 (Robert Anderson, MD, PhD, PI), U54 GM104938 (Judith James, MD, PhD, PI), the Oklahoma Center for the Advancement of Science and Technology HR15-108 (A.K.-J., PhD, PI), and the Ford Foundation Dissertation Fellowship (G.L.G.). This work was also supported by the U.S. Army Medical Research and Material Command (MRMC) Clinical and Rehabilitative Medicine Research Program (RAD5).

\section{AUTHOR DISCLOSURE AND GHOSTWRITING}

The opinions and assertions contained herein are the private views of the authors and are not to be construed as official or reflecting the views of the Department of Defense or the Department of the United States Army. No ghostwriters were used to write this article. Author H.A.P. discloses that she serves as Chief Scientist for the University of Oklahoma start-up company, Biolytx Pharmaceuticals Corp, and has equity in Biolytx. H.A.P., A.K.J., and G.L.G. are inventors on Canadian patent 2,893,504 and H.A.P. is an inventor on U.S. patents 9096679,7893027 , and 7354900 that are relevant to this review.

\section{ABOUT THE AUTHORS}

Gina L. Griffith, $\mathbf{P h D}$, received her $\mathrm{PhD}$ in Pathology from the University of Oklahoma Health Sciences Center in Oklahoma City, Oklahoma in 2013 in the laboratory of H. Anne Pereira. She currently serves as a Research Microbiologist in the Ocular Trauma and Vision Restoration at the United States Army Institute of Surgical Research in Fort Sam Houston, Texas. Anne Kasus-Jacobi, PhD, received her PhD in Endocrinology from the University of Paris XI in 1998. She is currently an Assistant Professor of Research in the Department of Pharmaceutical Sciences at the University of Oklahoma Health Sciences Center in Oklahoma City, Oklahoma. H. Anne Pereira, PhD, received her $\mathrm{PhD}$ in Pathology from the University of Melbourne, Australia in 1982. She is currently a Professor and Associate Dean of Research in the Department of Pharmaceutical Sciences and the Dean of the Graduate College University of Oklahoma Health Sciences Center in Oklahoma City, Oklahoma.

\section{REFERENCES}

1. Wilson SL, El Haj AJ, Yang Y. Control of scar tissue formation in the cornea: strategies in clinical and corneal tissue engineering. J Funct Biomater 2012;3:642-687.

2. Steinstraesser L, Koehler T, Jacobsen F, et al. Host defense peptides in wound healing. Mol Med 2008;14:528-537.
3. Brandt CR. Peptide therapeutics for treating ocular surface infections. J Ocul Pharmacol Ther 2014;30:691-699.

4. Spitznagel JK. Antibiotic proteins of human neutrophils. J Clin Invest 1990;86:1381-1386.

5. Teixeira V, Feio MJ, Bastos M. Role of lipids in the interaction of antimicrobial peptides with membranes. Prog Lipid Res 2012;51: 149-177.

6. Epand RM, Epand RF. Lipid domains in bacterial membranes and the action of antimicrobial agents. Biochim Biophys Acta 2009;1788:289-294.

7. Hong RW, Shchepetov M, Weiser JN, Axelsen PH. Transcriptional profile of the Escherichia coli 
response to the antimicrobial insect peptide cecropin A. Antimicrob Agents Chemother 2003;47:1-6.

8. Wimley WC. Describing the mechanism of antimicrobial peptide action with the interfacial activity model. ACS Chem Biol 2010;5:905-917.

9. Mojsoska B, Jenssen H. Peptides and peptidomimetics for antimicrobial drug design. Pharmaceuticals (Basel) 2015;8:366-415.

10. Wang G, Mishra B, Lau K, Lushnikova T, Golla R, Wang X. Antimicrobial peptides in 2014. Pharmaceuticals (Basel) 2015;8:123-150.

11. Yount NY, Bayer AS, Xiong YQ, Yeaman MR Advances in antimicrobial peptide immunobiology. Biopolymers 2006;84:435-458.

12. Nguyen LT, Haney EF, Vogel HJ. The expanding scope of antimicrobial peptide structures and their modes of action. Trends Biotechnol 2011; 29:464-472

13. Hayashi Y, Call MK, Chikama T, et al. Lumican is required for neutrophil extravasation following corneal injury and wound healing. J Cell Sci 2010;123:2987-2995.

14. Marrazzo G, Bellner L, Halilovic A, et al. The role of neutrophils in corneal wound healing in $\mathrm{HO}-2$ null mice. PLoS One 2011;6:e21180.

15. Carretero M, Escamez MJ, Garcia M, et al. In vitro and in vivo wound healing-promoting activities of human cathelicidin LL-37. J Invest Dermatol 2008;128:223-236.

16. Soehnlein 0, Lindbom L. Neutrophil-derived azurocidin alarms the immune system. J Leukoc Biol 2009;85:344-351.

17. Shafer WM, Martin LE, Spitznagel JK. Cationic antimicrobial proteins isolated from human neutrophil granulocytes in the presence of diisopropyl fluorophosphate. Infect Immun 1984;45:29-35.

18. Hancock R, Diamond G. The role of cationic antimicrobial peptides in innate host defences. Trends Microbiol 2000:402-410.

19. Pereira HA, Kumar P, Lerner MR, Brackett DJ. Inducible expression of the inflammatory protein CAP37 in the epidermis during wound healing. In: Robinson JW, ed. Focus on Protein Research. Hauppauge, NY: Nova Biomedical Publications 2004:127-144.

20. Heilborn JD, Nilsson MF, Kratz G, et al. The cathelicidin anti-microbial peptide LL-37 is involved in re-epithelialization of human skin wounds and is lacking in chronic ulcer epithelium. J Invest Dermatol 2003;120:379-389.

21. Ruan X, Chodosh J, Callegan MC, et al. Corneal expression of the inflammatory mediator CAP37. Invest Ophthalmol Vis Sci 2002;43:1414-1421.

22. Pereira HA, Ruan X, Gonzalez ML, TsyshevskayaHoover I, Chodosh J. Modulation of corneal epithelial cell functions by the neutrophil-derived inflammatory mediator CAP37. Invest Ophthalmol Vis Sci 2004;45:4284-4292.

23. Griffith GL, Russell RA, Kasus-Jacobi A, et al. CAP37 activation of PKC promotes human cor- neal epithelial cell chemotaxis. Invest Ophthalmol Vis Sci 2013:54:6712-6723.

24. Griffith GL, Kasus-Jacobi A, Lerner MR, Pereira HA. Corneal wound healing, a newly identified function of CAP37, is mediated by protein kinase $\mathrm{C}$ delta (PKCdelta). Invest Ophthalmol Vis Sci 2014; 55:4886-4895.

25. Pfister RR, Burstein NL. The normal and abnormal human corneal epithelial surface: a scanning electron microscope study. Invest Ophthalmol Vis Sci 1977;16:614-622.

26. McDermott AM. The role of antimicrobial peptides at the ocular surface. Ophthalmic Res 2009;41:60-75.

27. Nishimura M, Abiko Y, Kurashige $Y$, et al. Effect of defensin peptides on eukaryotic cells: primary epithelial cells, fibroblasts and squamous cell carcinoma cell lines. J Dermatol Sci 2004;36:87-95.

28. Van Wetering S, Mannesse-Lazeroms SP, Van Sterkenburg MA, Daha MR, Dijkman JH, Hiemstra PS. Effect of defensins on interleukin-8 synthesis in airway epithelial cells. Am J Physiol 1997;272:L888-896.

29. Bowdish DM, Davidson DJ, Speert DP, Hancock RE. The human cationic peptide LL-37 induces activation of the extracellular signal-regulated kinase and p38 kinase pathways in primary human monocytes. J Immunol 2004;172:3758-3765.

30. Liu CY, Kao WW. Corneal epithelial wound healing. Prog Mol Biol Transl Sci 2015;134:61-71.

31. Maycock NJ, Marshall J. Genomics of corneal wound healing: a review of the literature. Acta Ophthalmol 2014;92:e170-184.

32. Ashby B, Garrett 0 , Willcox M. Corneal injuries and wound healing-review of processes and therapies. Austin J Clin Ophthalmol 2014;1:25.

33. Dua HS, Gomes JA, Singh A. Corneal epithelial wound healing. Br J Ophthalmol 1994;78:401-408.

34. Lu L, Reinach PS, Kao WW. Corneal epithelial wound healing. Exp Biol Med (Maywood) 2001; 226:653-664.

35. Ambrosio R, Jr., Kara-Jose N, Wilson SE. Early keratocyte apoptosis after epithelial scrape injury in the human cornea. Exp Eye Res 2009;89:597-599.

36. Wilson SE, Kim WJ. Keratocyte apoptosis: implications on corneal wound healing, tissue organization, and disease. Invest Ophthalmol Vis Sci 1998;39:220-226.

37. Li Z, Burns AR, Smith CW. Two waves of neutrophil emigration in response to corneal epithelial abrasion: distinct adhesion molecule requirements. Invest Ophthalmol Vis Sci 2006;47:1947-1955.

38. Larjava H, Salo T, Haapasalmi K, Kramer $\mathrm{RH}$ Heino J. Expression of integrins and basement membrane components by wound keratinocytes. J Clin Invest 1993;92:1425-1435.

39. Gipson IK, Watanabe H, Zieske JD. Corneal wound healing and fibronectin. Int Ophthalmol Clin 1993;33:149-163.

40. Delwel G0, de Melker AA, Hogervorst F, et al. Distinct and overlapping ligand specificities of the alpha $3 A$ beta 1 and alpha $6 A$ beta 1 integrins: recognition of laminin isoforms. Mol Biol Cell 1994;5:203-215.

41. Mercurio AM. Laminin receptors: achieving specificity through cooperation. Trends Cell Biol 1995:5:419-423.

42. Filenius S, Hormia M, Rissanen J, et al. Laminin synthesis and the adhesion characteristics of immortalized human corneal epithelial cells to laminin isoforms. Exp Eye Res 2001;72:93-103.

43. Li J, Raghunath M, Tan D, Lareu RR, Chen Z, Beuerman RW. Defensins HNP1 and HBD2 stimulation of wound-associated responses in human conjunctival fibroblasts. Invest Ophthalmol Vis Sci 2006;47:3811-3819.

44. Li Z, Rumbaut RE, Burns AR, Smith CW. Platelet response to corneal abrasion is necessary for acute inflammation and efficient re-epithelialization. Invest Ophthalmol Vis Sci 2006;47:4794-4802.

45. Flodgaard H, Ostergaard E, Bayne S, et al. Covalent structure of two novel neutrophile leucocyte-derived proteins of porcine and human origin. Neutrophile elastase homologues with strong monocyte and fibroblast chemotactic activities. Eur J Biochem 1991;197:535-547.

46. Townsend B. Beyond our clinics: a vision for the future. Am J Occup Ther 1991;45:871-873.

47. Goldberg MF, Bron AJ. Limbal palisades of Vogt. Trans Am Ophthalmol Soc 1982;80:155-171.

48. Hanna C, O’Brien JE. Cell production and migration in the epithelial layer of the cornea. Arch Ophthalmol 1960;64:536-539.

49. Gipson IK. Adhesive mechanisms of the corneal epithelium. Acta Ophthalmol Suppl 1992:13-17.

50. Gipson IK, Spurr-Michaud S, Tisdale A, Keough M. Reassembly of the anchoring structures of the corneal epithelium during wound repair in the rabbit. Invest Ophthalmol Vis Sci 1989;30:425-434.

51. Owens BD, Kragh JF, Jr., Wenke JC, Macaitis J, Wade CE, Holcomb JB. Combat wounds in operation Iraqi freedom and operation enduring freedom. J Trauma 2008;64:295-299.

52. Colyer MH, Chun DW, Bower KS, Dick JS, Weichel ED. Perforating globe injuries during operation Iraqi Freedom. Ophthalmology 2008;115:2087-2093.

53. Weichel ED, Colyer MH, Ludlow SE, Bower KS, Eiseman AS. Combat ocular trauma visual outcomes during operations iraqi and enduring freedom. Ophthalmology 2008;115:2235-2245.

54. Charters L. Protective eye gear essential for modern soldier. Ophthalmology Times 2007;32:9.

55. Cho RI, Savitshy E. Ocular trauma. In: Savitshy E, Eastridge B, eds. Combat Casulty Care: Lessons Learned from OEF and OIF. Fort Detrick, MD: Office of The Surgeon General 2012:299-342.

56. Collier SA, Gronostaj MP, MacGurn AK, et al. Estimated burden of keratitis. Morb Mortal Wkly Rep 2010;63:1027-1030.

57. Merle H, Gerard M, Schrage N. [Ocular burns]. J Fr Ophtalmol 2008;31:723-734 (Article in French). 
58. Shrivastava P, Goel A. Pre-hospital care in burn injury. Indian J Plast Surg 2010;43:S15-S22.

59. National Society to Prevent Blindness. Visual problems in the U.S. data analysis definitions. Data sources, detailed data tables, analysis, interpretation. New York: National Society to Prevent Blindness, 1980:1-46.

60. Ozkurt ZG, Yuksel H, Saka G, Guclu H, Evsen S, Balsak S. Metallic corneal foreign bodies: an occupational health hazard. Arq Bras Oftalmol 2014;77:81-83.

61. Pepose JS, Wilhelmus KR. Divergent approaches to the management of corneal ulcers. Am J Ophthalmol 1992;114:630-632.

62. Chang VS, Dhaliwal DK, Raju L, Kowalski RP. Antibiotic resistance in the treatment of Staphylococcus aureus keratitis: a 20-year review. Cornea 2015;34:698-703.

63. Willcox MD. Review of resistance of ocular isolates of $P$ seudomonas aeruginosa and staphylococci from keratitis to ciprofloxacin, gentamicin and cephalosporins. Clin Exp Optom 2011;94:161-168.

64. Sy A, Srinivasan M, Mascarenhas J, et al. Pseudomonas aeruginosa keratitis: outcomes and response to corticosteroid treatment. Invest Ophthalmol Vis Sci 2012;53:267-272.

65. Morgan JG, Pereira HA, Sukiennicki T, Spitznagel JK, Larrick JW. Human neutrophil granule cationic protein CAP37 is a specific macrophage chemotaxin that shares homology with inflammatory proteinases. Adv Exp Med Biol 1991;305:89-96.

66. Gibson TL, Cohen P. Inflammation-related neutrophil proteases, cathepsin $\mathrm{G}$ and elastase, function as insulin-like growth factor binding protein proteases. Growth Horm IGF Res 1999;9:241-253.

67. Pohl J, Pereira HA, Martin NM, Spitznagel JK. Amino acid sequence of CAP37, a human neutrophil granule-derived antibacterial and monocyte-specific chemotactic glycoprotein structurally similar to neutrophil elastase. FEBS Lett 1990;272:200-204.

68. Iversen LF, Kastrup JS, Bjorn SE, et al. Structure and function of the N-linked glycans of HBP/ CAP37/azurocidin: crystal structure determination and biological characterization of nonglycosylated HBP. Protein Sci 1999;8:2019-2026.

69. Barrett AJ, Rawlings ND. Families and clans of serine peptidases. Arch Biochem Biophys 1995; 318:247-250.

70. Pereira HA, Shafer WM, Pohl J, Martin LE, Spitznagel JK. CAP37, a human neutrophilderived chemotactic factor with monocyte specific activity. J Clin Invest 1990;85:1468-1476.

71. Brandt K, Lundell K, Brismar K. Neutrophilderived azurocidin cleaves insulin-like growth factor-binding protein-1, -2 and -4 . Growth Horm IGF Res 2011;21:167-173.

72. Jones JI, Clemmons DR. Insulin-like growth factors and their binding proteins: biological actions. Endocr Rev 1995;16:3-34.

73. Chertov 0 , Ueda $\mathrm{H}, \mathrm{Xu} \mathrm{LL}$, et al. Identification of human neutrophil-derived cathepsin $G$ and
azurocidin/CAP37 as chemoattractants for mononuclear cells and neutrophils. J Exp Med 1997:186:739-747.

74. Pereira HA, Erdem I, Pohl J, Spitznagel JK. Synthetic bactericidal peptide based on CAP37: a 37kDa human neutrophil granule-associated cationic antimicrobial protein chemotactic for monocytes. Proc Natl Acad Sci U S A 1993:90:4733-4737.

75. Shafer WM, Engle SA, Martin LE, Spitznagel JK. Killing of Proteus mirabilis by polymorphonuclear leukocyte granule proteins: evidence for species specificity by antimicrobial proteins. Infect Immun 1988;56:51-53.

76. Pereira HA, Tsyshevskaya-Hoover I, Hinsley H, et al. Candidacidal activity of synthetic peptides based on the antimicrobial domain of the neutrophil-derived protein, CAP37. Med Mycol 2010;48:263-272.

77. Sun Y, Shang D. Inhibitory effects of antimicrobial peptides on lipopolysaccharide-induced inflammation. Mediators Inflamm 2015;2015:167572.

78. Shai Y. Mode of action of membrane active antimicrobial peptides. Biopolymers 2002;66:236-248.

79. Nelson DE, Ihekwaba AE, Elliott M, et al. Oscillations in NF-kappaB signaling control the dynamics of gene expression. Science 2004;306:704-708.

80. Lawrence T. The nuclear factor NF-kappaB pathway in inflammation. Cold Spring Harb Perspect Biol 2009;1:a001651.

81. Brothers KM, Stella NA, Hunt KM, et al. Putting on the brakes: bacterial impediment of wound healing. Sci Rep 2015;5:14003.

82. Brackett DJ, Lerner MR, Lacquement MA, He R, Pereira HA. A synthetic lipopolysaccharide-binding peptide based on the neutrophil-derived protein CAP37 prevents endotoxin-induced responses in conscious rats. Infect Immun 1997;65:2803-2811.

83. Marra MN, Wilde CG, Griffith JE, Snable JL, Scott RW. Bactericidal/permeability-increasing protein has endotoxin-neutralizing activity. J Immunol 1990;144:662-666.

84. Scott MG, Yan H, Hancock RE. Biological properties of structurally related alpha-helical cationic antimicrobial peptides. Infect Immun 1999;67:2005-2009.

85. Heinzelmann M, Mercer-Jones MA, Flodgaard H, Miller FN. Heparin-binding protein (CAP37) is internalized in monocytes and increases LPSinduced monocyte activation. J Immunol 1998; 160:5530-5536.

86. Soehnlein 0, Kai-Larsen $Y$, Frithiof $R$, et al. Neutrophil primary granule proteins HBP and HNP1-3 boost bacterial phagocytosis by human and murine macrophages. J Clin Invest 2008;118:3491-3502.

87. Pereira HA, Moore P, Grammas P. CAP37, a neutrophil granule-derived protein stimulates protein kinase $C$ activity in endothelial cells. J Leukoc Biol 1996;60:415-422.

88. Gessani S, Belardelli F. IFN-gamma expression in macrophages and its possible biological significance. Cytokine Growth Factor Rev 1998;9:117-123.
89. Frucht DM, Fukao T, Bogdan C, Schindler $H_{\text {, }}$ O'Shea JJ, Koyasu S. IFN-gamma production by antigen-presenting cells: mechanisms emerge. Trends Immunol 2001;22:556-560.

90. Stark GR, Kerr IM, Williams BR, Silverman RH, Schreiber RD. How cells respond to interferons. Annu Rev Biochem 1998;67:227-264.

91. Tortorella D, Gewurz BE, Furman MH, Schust DJ, Ploegh HL. Viral subversion of the immune system. Annu Rev Immunol 2000;18:861-926.

92. Lam H, Bleiden L, de Paiva CS, Farley W, Stern ME, Pflugfelder SC. Tear cytokine profiles in dysfunctional tear syndrome. Am J Ophthalmol 2009;147:198-205 e191.

93. Watanabe M, Ueno Y, Yajima T, et al. Interleukin 7 is produced by human intestinal epithelial cells and regulates the proliferation of intestinal mucosal lymphocytes. J Clin Invest 1995;95:2945-2953.

94. Sin JI, Kim J, Pachuk C, Weiner DB. Interleukin 7 can enhance antigen-specific cytotoxic-Tlymphocyte and/or Th2-type immune responses in vivo. Clin Diagn Lab Immunol 2000;7:751-758.

95. Maurer M, von Stebut E. Macrophage inflammatory protein-1. Int J Biochem Cell Biol 2004; 36:1882-1886.

96. Di Sabatino A, Calarota SA, Vidali F, Macdonald TT, Corazza GR. Role of IL-15 in immunemediated and infectious diseases. Cytokine Growth Factor Rev 2011;22:19-33.

97. Yong KL. Granulocyte colony-stimulating factor (G-CSF) increases neutrophil migration across vascular endothelium independent of an effect on adhesion: comparison with granulocytemacrophage colony-stimulating factor (GM-CSF). Br J Haematol 1996;94:40-47.

98. Pelletier M, Girard D. Interleukin-15 increases neutrophil adhesion onto human respiratory epithelial A549 cells and attracts neutrophils in vivo. Clin Exp Immunol 2005;141:315-325.

99. Menten P, Wuyts A, Van Damme J. Macrophage inflammatory protein-1. Cytokine Growth Factor Rev 2002;13:455-481.

100. Tran MT, Tellaetxe-Isusi M, Elner V, Strieter RM, Lausch RN, Oakes JE. Proinflammatory cytokines induce RANTES and MCP-1 synthesis in human corneal keratocytes but not in corneal epithelial cells. Beta-chemokine synthesis in corneal cells. Invest Ophthalmol Vis Sci 1996;37:987-996.

101. Takano Y, Fukagawa K, Shimmura S, Tsubota K, Oguchi Y, Saito H. IL-4 regulates chemokine production induced by TNF-alpha in keratocytes and corneal epithelial cells. $\mathrm{Br} \mathrm{J}$ Ophthalmol 1999;83:1074-1076.

102. Cubitt CL, Lausch RN, Oakes JE. Synthesis of type II interleukin-1 receptors by human corneal epithelial cells but not by keratocytes. Invest Ophthalmol Vis Sci 2001;42:701-704.

103. Wilson SE, He YG, Weng J, et al. Epithelial injury induces keratocyte apoptosis: hypothesized role for the interleukin-1 system in the modulation of corneal tissue organization and wound healing. Exp Eye Res 1996;62:325-327. 
104. Wilson SE, Schultz GS, Chegini N, Weng J, He YG. Epidermal growth factor, transforming growth factor alpha, transforming growth factor beta, acidic fibroblast growth factor, basic fibroblast growth factor, and interleukin1 proteins in the cornea. Exp Eye Res 1994;59: 63-71.

105. Gomez-Cambronero J, Horn J, Paul CC, Baumann MA. Granulocyte-macrophage colony-stimulating factor is a chemoattractant cytokine for human neutrophils: involvement of the ribosomal p70 S6 kinase signaling pathway. J Immunol 2003;171: 6846-6855.

106. Kasus-Jacobi A, Noor-Mohammadi S, Griffith GL, Hinsley H, Mathias L, Pereira HA. A multifunctional peptide based on the neutrophil immune defense molecule, CAP37, has antibacterial and wound-healing properties. J Leukoc Biol 2015; 97:341-350.

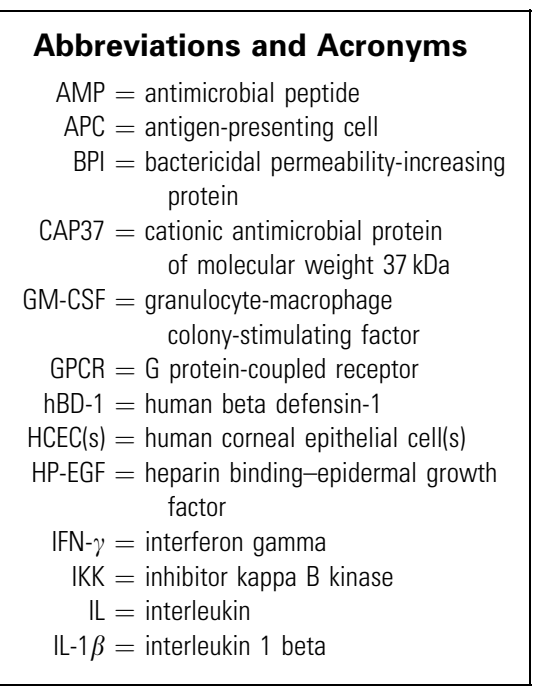

$\mid \kappa \mathrm{B} \alpha=$ inhibitor kappa B alpha

$\mathrm{KC}=$ keratinocyte chemoattractant

LPS $=$ lipopolysaccharide

LTA $=$ lipoteichoic acids

MIP1- $\alpha=$ macrophage inflammatory protein 1 alpha

MIP1- $\beta=$ macrophage inflammatory protein 1 beta

MRSA $=$ methicillin-resistant $S$. aureus

$\mathrm{NEI}=$ National Eye Institute

$\mathrm{NF}-\kappa \mathrm{B}=$ nuclear factor kappa $\mathrm{B}$

$\mathrm{PCED}=$ persistent corneal epithelial defect

$\mathrm{PKC}=$ protein kinase $\mathrm{C}$

$\mathrm{PMN}=$ polymorphonuclear neutrophils

SEM $=$ standard error of the mean

TLR4 $=$ toll-like receptor 4

TNF- $\alpha=$ tumor necrosis factor alpha 